\title{
MANIPULATING TRUTH IN MEDIA DISCOURSE
}

\section{Zorica Trajkova}

Ss. Cyril and Methodius University, Skopje

trajkova_zorica@flf.ukim.edu.mk

ORCID ID: https://orcid.org/0000-002-2346-978X

This paper aims to investigate the language journalists use to present news from a certain perspective and thus create public opinion. More precisely, it offers a critical discourse analysis of Macedonian and American journalistic texts reporting on one and the same political event. The main goal is to compare and contrast the specific language tools (lexical-semantic, pragmatic and stylistic) employed in the journalistic texts with different political affiliation.

The analysis reveals that there is interrelatedness between textual form and content. Journalists make a careful selection of persuasive strategies to frame the news and present it from certain, often 'personal', perspective. The intentionally and cautiously chosen lexical units, pragmatic markers and rhetorical tropes help journalists manipulate the news and present it in such a way that it supports a specific political cause. In this way, they tend to influence the opinions of the people and indirectly impact the political and social situation in the country.

Key words: newspaper articles, pragmatic markers, lexical-semantic analysis, rhetorical tropes, persuasion 


\title{
МАНИПУЛИРАЬЕ СО ВИСТИНАТА ВО НОВИНАРСКИОТ ДИСКУРС
}

\author{
Зорица Трајкова \\ Универзитет „Св. Кирил и Методиј“, Скопје \\ trajkova_zorica@flf.ukim.edu.mk \\ ORCID ID: https://orcid.org/0000-002-2346-978X
}

Овој труд има за цел да ги истражи јазичните стратегии кои новинарите ги употребуваат за да презентираат вести од одредена перспектива и на тој начин да го креираат јавното мислење. Поточно, трудот прави критичко дискурсна анализа на македонски и американски новинарски текстови кои известуваат за еден ист политички настан. Главната цел е да се споредат специфичните јазични средства (лексичко-семнтички, прагматички и стлистички) кои се употребени во новинарски текстови кои поддржуваат различна политичка опција. Поточно, фокусот е на лексичко-семантичка, прагматичка и реторичка анализа на статии од весници напишани на една иста тема во двете земји, Македонија и Америка.

Анализата открива дека постои тесна корелација помеѓу текстуалната форма и содржината. Новинарите прават внимателна селекција на убедливи стратегии за да ја „врамат“ веста и да ја презентираат од одредена, често лична, перспектива. Намерно и внимателно избраните лексички единици, прагматички маркери и реторички тропи им помагаат на новинарите да манипулираат со веста и да ја претстават во корист на одредена политичка опција. На овој начин тие влијаат на општото јавно мислење и индиректно влијаат на политичката и општествената состојба во државата.

Клучни зборови: новинарски статии, прагматички маркери, лексичкосемантичка анализа, реторички тропи, убедување 


\section{Introduction}

This paper focuses on analysis of the strategies journalists use to frame political news in order to influence the readers and shape their opinion. Framing is very often used by both politicians and the media as a tool to influence social policies and the institutions that carry out those policies. Goffman $(1974,1986)$, who put forth the framing theory states that framing works to shape and alter audience members' interpretations and preferences. News could be construed in such a way that the audience is told not just what to think about but also how to think about some specific issue. Journalists may frame the news by portraying an issue from one perspective to the necessary exclusion of alternative perspectives. As a result, the presented news is biased. Entman (2007: 163) suggests three major meanings assigned to the term bias: news that distorts or falsifies reality (distortion bias); news that favors one side rather than provide equivalent treatment to both sides in a political conflict (content bias) and motivations and mindsets of journalists who allegedly produce the biased content (decision-making bias).

When analysing a newspaper article one needs to work out what the writer is doing through discourse and how this "doing" is linked to wider inter-personal, institutional, socio-cultural and material contexts (Richardson 2007). According to Richardson (2007), language use has power and is political because it is shaped for specific purposes and can corrupt thought. However, insightful readers, are often puzzled when they read different versions of the same news in various newspapers and realise that the truth has been distorted.

This was the main motivation for the research done in this paper. The aim is to present the results of a critical discourse analysis (CDA) of two samples of journalistic texts, Macedonian and English, which report on one and the same political event. There is a lack of such research in Macedonian linguistics and the results of this analysis might set a basis for future explorations in this area. CDA links linguistic to social analysis (Woods and Kroger 2000: 206). 'Manipulation' is one of the crucial notions of Critical Discourse and it is a form of social power abuse, cognitive mind control and discursive interaction (Van Dijk 2006: 359). What characterises manipulation is power and domination (Van Dijk 2006: 362).

In order to show how power is abused by journalists, the paper presents a more detailed analysis of the lexical-semantic, pragmatic and rhetorical strategies they employ to present news from a certain perspective. Samples of texts from both Macedonian and American newspapers is analysed and the reason for the contrastive analysis is to determine whether the strategies journalists employ are universal or they are culture-based. Hence, the paper focuses on giving answer to two main research questions: 
1. Do journalists use language to manipulate news (especially one connected to politics or political leaders) and present it in such way that they take sides?

2. Is there any difference between Macedonian and American journalists in this respect?

The paper is organised in five sections. The following section discusses relevant theoretical issues on media bias. The third section focuses on the collected data and research methodology. The fourth section discusses the results from a detailed lexical-semantic, pragmatic and rhetorical analysis. Finally, in the fifth part, relevant conclusions are drawn.

\section{Media discourse: Newspaper articles and bias}

Several authors (Fairclough 1995; Talbot 2007; Bednarek 2006 among others) have tried to define media discourse. O'Keefee (2011: 441), for instance, refers to it as "interactions that take place through a broadcast platform, whether spoken or written, in which the discourse is oriented to a non-present reader, listener or viewer. [...] It is a public, manufactured, on-record form of interaction". Newspaper discourse, as a type of media discourse, has also been the focus of research of several authors (Fairclough 1995; Bednarek 2006; Richardson 2007; Fowler 1991; van Dijk 1991 and others), but O'Keeffe (2011: 442) believes that although it is easily accessible and "fruitful" for analysis, it has been understudied: "Given the superfluity of newspapers and the daily role they have in meaningmaking, it is surprising how few linguistic studies there are, proportionally, of how they use language".

When analysing newspaper articles the focus should be on the language used by writers, the manner in which it is employed and linked to the wider socio-cultural context. Reah (2002), for instance, analyses headline creation, newspaper audiences and their role and relationship with and for newspapers, lexical choice, syntax and discourse on the building and manipulation of meaning. Bednarek (2006) analyses 100 newspaper articles, both from broadsheet and tabloid media, and gives detailed explanations and justifications of bias in newspapers. Richardson (2007) investigates the inter-related nature of textual form and content, by doing micro-textual analysis i.e., analysis of the use of words (lexis) and sentences (syntax and modality) and macro-textual analysis (how propositions are combined, rhetoric). Wadi and Ahmed (2015) conduct a research very similar to the one presented here on language manipulation in media. They show through a critical discourse analysis how one and the same news is reported differently by different sources of media with the aim to manipulate readers' opinion of it. 


\subsection{Media framing}

When analysing news one has to take into consideration how people receive the presented information and how they reason. People think in frames or mental pictures or mind maps (see for instance Wheeldon and Faubert 2009). They are abstractions that work to organise or structure the meaning of the message. Or, as Entman (2007: 164) states: "frames introduce or raise the salience or apparent importance of certain ideas, activating schemas that encourage target audiences to think, feel, and decide in a particular way". The cognitive linguist Lakoff (2004: xv) defines frames as "mental structures that shape the way we see the world."

Media framing can simply be described as the perspective from which a news story is told. News could be construed as a form of second level agenda-setting i.e., it does not only tell the audience what to think about (agenda-setting theory), but also how to think about that issue (second level agenda setting, framing theory). ${ }^{1}$ Goffman $(1974,1986)$, who put forth the framing theory, states that framing works to shape and alter audience members' interpretations and preferences.

Framing is very often used by politicians as a tool to influence social policies and the institutions that carry out those policies. Many world newspapers have cited Lakoff who comments about how President Donald Trump uses framing and is currently winning the linguistic war. According to Lakoff, he has "turned words into weapons" and journalists, "are providing additional ammunition". ${ }^{2}$ Journalists may work in favour of politicians and help them to gain and keep power, or they may strip politicians of power.

\section{Collected data and research methodology}

For the purposes of this research, eight newspaper articles were selected, four from Macedonian newspapers (the Republika, the Večer, the Utrinski Vesnik and the Deutsche Welle - $D W^{3}$ ) reporting on a same political event and four articles from American newspapers (the USA Today, the New York Post, The New York Times and the New York Daily News) also reporting on a same event. The events presented in the articles happened in $2016^{4}$ in both countries.

\footnotetext{
${ }^{1}$ Mass Communication Theory (Online), 2017.

2 For more, see: https://money.cnn.com/2018/06/15/media/reliable-sources-podcastgeorge-lakoff/index.html; or https://www.theguardian.com/commentisfree/2018/jun/13/how-to-report-trump-mediamanipulation-language

${ }^{3}$ The Deutche Welle $-D W$ in Macedonian.

${ }^{4}$ The period has no influence whatsoever on the aim of this research.
} 
As for the Macedonian sample, the analysis focuses on four articles (see their headlines 1-4 below) concerning the Special Public Prosecution (SPP) ${ }^{5}$ and their report about the wiretapping scandal. The case was shortly the following: allegedly the Government of the ruling right-wing party (VMRO) at the time (in 2016), had wiretapped about twenty thousand distinguished citizens in the country. This information was leaked to the left-wing party $\operatorname{SDSM}^{6}$ (then-opposition party) and its leader Zoran Zaev, who got hold of the recordings and presented some of them publicly. They revealed criminal activities committed by the Prime minister and some Government officials. Since people's trust in the existing criminal court was very low, a Special Public Prosecution (SPP) was formed to investigate the case. The articles under scrutiny in this research had been written after the main public prosecutor Katica Janeva revealed the illegal activities and named the case "Titanic", alluding to the sinking of the Titanic and the expected demise of the government. The four articles, each of which is approximately 1000 words long, are as follows:

1. The SPP with Absurd and Unfounded Suspicions Which Rather Than Legal Grounds Have Political Function [CJO со апсурдни и неиздржани сомневања кои наместо правна поткрепа имаат политичка функција], the Republika, 17/02/2016;

2. With the Forgeries of Čauš, Katica Springs to Zaev's Defence [Co фалсификатите на Чауш, Катица тргна во одбрана на Заев], the Večer, 12/02/2016;

3. Janeva Started "Titanic” [Јанева го отвори „Титаник“], the Utrinski vesnik, 12/02/2016; and

4. The Reel Begins to Unwind: The Judges are to be Tested Now [Клопчето почна да се одмотува: сега судиите се на тест], the Deutsche Welle, $12 / 02 / 2016$.

Two of the selected Macedonian newspapers (the Republika and the Večer) are known to be more right-wing oriented and in support of the Government at the time. The third one, the Utrinski vesnik is more left-wing oriented leaning to support of the then-opposition party SDSM. And the last one the Deutsche Welle, is supposed to be the most impartial one of all.

The four selected articles from the American sample were all reporting on the announcement made by Donald Trump in 2016 that he would seek the Republican nomination for president. The articles from this sample are somewhat shorter (550 -1000 words long). Their headlines ( $5-8$ below) read:

5. This Time, Donald Trump Says He's Running, the USA Today, 17/06/2015

\footnotetext{
${ }^{5}$ More about this on http://en.jonsk.mk/

${ }^{6}$ In 2017 elections, the left-wing SDSM won the elections. The right-wing VMRO was defeated and became the biggest opposition party.
} 
6. "I Will Be The Greatest Jobs President That God Has Ever Created": Trump, the New York Post, 16/06/2015

7. Donald Trump, Pushing Someone Rich, Offers Himself, The New York Times 16/06/2015

8. Donald Trump Enters 2016 Presidential Race With Bizarre Speech Insulting Mexican Immigrants, Lambasting Obama, the New York Daily News 17/06/2015

The USA Today is known to be pro-democratic and also rather neutral in its orientation, the New York Post is considered to be conservative and supportive of the Republicans, while The New York Times and the New York Daily News favour liberal causes and are critical of the Republicans.

The main research focus in this paper is on the strategies journalists use to present political news from a certain perspective and manipulate the truth and the readers. For that purpose, the paper conducts a Critical discourse analysis (CDA) of the selected texts. The analysis is in accordance with Fairclaugh's (1995) three dimensions to every discursive event:

1. Text (analysis) - choice;

2. Discursive practice - encoding and decoding meaning; and

3. Social practice - socio-cultural goings-on as part of the communicative event.

First, it provides the social setting for the events presented in the journalists' texts, focusing on three aspects:

1. the choice of words and phrases (lexical-semantic analysis)

2. use of meta-language: modality and evidentiality (pragmatic analysis)

3. use of rhetorical figures or tropes (stylistic analysis)

The analysis is based on three assumptions: ${ }^{7}$

Hypothesis 1: The choice of lexis, meta-language and rhetorical devices when presenting news helps journalists to shape the news and present it from a certain perspective;

Hypothesis 2: There will be difference among the analysed newspapers in the linguistic choices they make when presenting the same news;

7 These assumptions mostly derive from the author's personal experience as a socially involved newspaper reader. 
Hypothesis 3: Journalists both from Macedonia and the USA are biased and take sides.

\section{Research results and discussion}

In this section, as it was previously mentioned, the texts are analysed critically from three different aspects. First, the analysis focuses on the lexical choices made by journalists with the aim to see how they use lexis to positively or negatively frame politicians or political parties discussed in their texts. The ensuing pragmatic analysis is focused on metadiscourse markers that express modality and evidentiality. Finally, the use of rhetorical tropes is investigated and discussed.

\subsection{Lexical analysis}

The choice of lexis in political news is neither naive nor random. Texts are carefully crafted to reach the readers and affect their opinion concerning the politicians or the current political events. According to Richardson (2007: 49), "the way that people and events are named in news discourse can have significant impact on the way in which they are viewed [...]. Journalists have to provide names for the people in the events they report and this naming always involves choice". Reisigl and Wodak (2001: 47) call these naming options a text's 'referential strategies'. Van Dijk (2006) has developed a conceptual tool which determines choices between referential strategies distinguishing between a Positive Self-Presentation and a simultaneous Negative Other-Presentation. These two complementary strategies focus on participants as social groups rather than individuals (Van Dijk 2009). In the specific samples of texts, it is expected that journalists will create a positive frame of the politicians or political institutions/ parties they support and negative frame of the others - the opposition party or politician.

\subsubsection{Macedonian data}

The analysis of the Macedonian articles very clearly shows that journalists who write for newspapers which support certain ideology make positive lexical choices when they describe the party or the ideology of the party they support, and negative to describe the "other". More specifically, the journalists writing for newspapers which are mostly right-wing oriented, tried to create a negative frame of the SPP, presenting it as biased and mostly working in favour of the opposition helping it to bring down the Government. As expected, they used negative lexis to describe their work. On the other hand, the articles written in the more neutral newspapers were mostly factual and the journalists did not express their subjective opinion to describe the work of the SPP. That could be seen immediately from the headlines (see §3). The Republika and the Večer accuse the SPP and Katica Janeva for making 
absurd and unfounded suspicions expressing doubts in the SPP's objectivity. The Utrinski vesnik chooses a rather neutral headline, informing that the opening of the case, and the Deutsche Welle states that things have come out into the open but it is now up to the judges to take action. The detailed analysis of the articles confirmed these conclusions.

For instance, the journalist writing for the Republika negatively framed the work of the $\mathrm{SPP}^{8}$ describing it as:

(1) ... without any arguments but its sole purpose being to cause political harm $^{9}$.

(2) ... ridiculousness and the absurd in the rationale for the investigation written by Janeva and the special prosecutors. ....absurd and unfounded suspicions- with no legal support and political function.

In order to support their claim, the journalist also relies on some unindentified "expert's opinion" about the work of the SPP:

... they aim at gaining political points in favour of SDSM and causing damage to the rating of VMRO-DPMNE.

...scant and unfounded suspicions are what mainly characterizes the work of SPP.

As it can be seen, the focus of the journalist in this article is on discrediting the work of the SPP and presenting it as unnecessary and absurd. The expertise and objectivity of the SPP has been constantly challenged in this article by negative word choice. The journalist states that the investigation is conducted without any arguments, and is calling it ridiculous, absurd, with no legal support, and with unfounded suspicions.

The situation is similar to the content presented in the Večer where the journalist also creates a negative framing of the SPP, especially of the main public prosecutor Janeva. She is accused of conspiring against the Government by stating that she is simply pursuing the opposition party's agenda (see examples 6-9):

...the "thorough investigation" of Janeva is nothing more than simply pursuing the agenda in favour of the SDSM leader, Zaev.

\footnotetext{
${ }^{8}$ All examples have been translated into English.

${ }^{9}$ Although the focus of the analysis were the lexical choices (words, phrases, collocations), the wider context is also provided to illustrate the argument more clearly.
} 
(7) Janeva insists on putting Zoran Zaev under her jurisdiction and thus under her protection...

Janeva's mission is to “come to Zaev's rescue”.

On the other hand, the Utrinski vesnik reports rather neutrally on the activities of SPP quoting the exact words of the public prosecutors and presenting only very few journalists' comments. These comments mainly contained facts (detention was proposed, investigation against five judges is initiated etc.). See for instance examples (9)-(11):

(9) the SPP proposed detention of eight people...

(10) The case (...) is formed and a great number of investigative actions are taken as a result of many clues and solid evidence.

(11) An investigation against five judges is also initiated...

The journalist writing for the Deutsche Welle also did not give any subjective comments on the work of the prosecutors (for example, detention is suggested, investigation is initiated). To support their claims, they cited mostly the words of the public prosecutors and experts (see examples 12 and 13).

(12) Detention is suggested against certain people...

(13) The SPP announced that an investigation is initiated against members of the local election commission in Chair.

\subsubsection{American data}

The analysis of the American texts showed similar results. Journalists who wrote for newspapers which are pro-Republican framed Trump rather positively (the New York Post, for instance), while those, generally critical of Republicans, created a rather negative frame of Trump, mocking him and his nomination (The New York Times and the New York Daily News). The journalist writing for the USA Today was rather objective and even supportive of Trump, which could be also seen from the headlines. The two newspapers The New York Times and the New York Daily News were rather critical and even offensive towards Trump's nomination using words and phrases such as: pushes, offers himself, bizarre speech, insulting etc.); the USA Today seems to have chosen a very neutral title which only reports that Trump is running for president, while the New York Post cites Trump's words in a positive connotation using superlatives to describe him (the greatest jobs president that God has ever created). The detailed analysis of the whole articles confirmed this conclusion. 
For instance, the article in the USA Today focused on Donald Trump, and the tone fluctuates from neutral: the host of television's The Apprentice; the real estate magnate and reality $T V$ star, to rather supportive, presenting him as a good candidate: tough negotiator, outspoken critic, confident etc. (see examples (14-18).

(14) But the host of television's The Apprentice (and Celebrity Apprentice) made moves...

(15) The real-estate magnate and reality TV star - who has toyed with presidential campaigns before - announced Tuesday that he would seek the Republican nomination for president in 2016.

(16) He portrayed himself as a tough negotiator and entrepreneur who can succeed where political leaders have failed.

(17) Trump has been an outspoken critic of President Obama...

(18) If there's one thing Trump brings to the 2016 campaign, it's confidence.

The following examples (19)-(21), are taken from The New York Post article. As it can be seen, the journalist uses rather positive lexis to describe Trump. His speech is presented as red-meat, and his style as moxie and pugnacious, attacking the entrenched Washington.

(19) "I will be the greatest jobs president that God has ever created," the billionaire declared during a 45-minute red-meat speech...

(20) The mogul, known for his "You're fired"-style moxie and pugnacious oratory style, took no prisoners, slamming Jeb Bush, President Obama, Hillary Rodham Clinton...

(21) Taking the stage to Neil Young's "Rockin' in the Free World," Trump painted himself as a political outsider, attacking the entrenched Washington, DC, establishment...

In contrast, examples (22)-(33) depict lexical choices made in both The New York Times and New York Daily News. In both articles, the journalists framed Trump as an inappropriate candidate. Their reports were critical of Trump's nomination and his speech. For instance, the journalist from The New York Times described Trump as a disliked garrulous real estate developer who boasts, brags and provokes, and is on an improbable quest for the Republican nomination. 
(22) Donald J. Trump, the garrulous real estate developer (...), announced on Tuesday his entry into the 2016 presidential race, brandishing his wealth and fame as chief qualifications in an improbable quest for the Republican nomination.

(23) Mr. Trump, 69, has long toyed with running for president as a Republican, boasting of his credentials as an entrepreneur and mocking the accomplishments of prominent elected officials.

(24) He bragged extensively about the golf resorts he owns...

(25) But as well-known as he is, Mr. Trump is also widely disliked:...

(26) Mr. Trump's policy views can be just as provocative as his demeanor.

The New York Daily News went even further in their attacks: not only did they criticise, but also insulted Trump by comparing him to a clown with a red-rubber nose who delivered a jaw-dropping ad-libbed speech. At the same time, they attempted to diminish the number of people attending the event and their opinion of Trump. See examples (27)-(33) below.

(27) The carload of Republicans running for President now has a clown.

(28) Billionaire Donald Trump threw his red-rubber nose into the ring Tuesday with a jaw-dropping ad-libbed speech...

(29) The real estate magnate made a less-than-imperial entrance, emerging on the main floor of the building...

(30) A crowd that appeared to number in the hundreds (...) to hear the bluntspoken billionaire.

(31) In a series of rants about China, Trump bragged he had recently sold an apartment.

(32) He went on to tout his wealth as proof he could run the country.

(33) Amid eyebrow-raising statements, Trump laid out a platform including killing President Obama's proposed trade deal with Asia...

It can be concluded that journalists make lexical choices with positive connotation to refer to things their newspaper supports and choices with negative connotation to criticise and take an opposing or negative stance. In this way, they 
are attempting to influence the readership's opinion on the specific issue discussed. Journalists who are less biased tend to use more factual language.

\subsection{Pragmatic analysis: Modality and evidentiality}

This section presents a more thorough pragmatic analysis of the texts. By investigating the use of specific metadiscourse markers, the analysis aims to show how authors modify their statements and express their personal subjective opinion.

\subsubsection{Modality}

Modality refers to "the writer's attitude towards, or opinion about, the truth of a proposition expressed by the sentence (Simpson 1993: 47). It also extends to "their attitude towards the situation or event described by a sentence". In order to investigate the journalists' attitude towards the truth of their propositions, the texts were analysed for the use of metadiscourse markers, ${ }^{10}$ or the text the writers employed to comment on their text. More precisely, the analysis focused on interpersonal metadiscourse markers (hedges, intensifiers and attitude markers) as one type of metadiscourse markers which show authors' attitude towards the content presented in their arguments (Hyland 2005). Authors usually employ intensifiers (or boosters) to emphasise "important" information and show confidence in the truth value of their statements, while they use hedges to diminish the importance of another information, and to express tentative statements when facts or evidence to support their arguments are lacking. To support personal attitudes authors employ attitude markers.

The analysis of the Macedonian texts showed that the journalists generally avoided using hedges, but employed intensifiers instead. This was especially the case with the journalists writing for the Republika and the Večer, supportive of the government and critical of the SPP. The semantics of the intensifiers (verbs, adjectives, adverbs and nouns) indicate the journalists' intention to intensify the persuasive effect of their arguments. The following choice of lexis was registered:

- verbs such as show and bombarded, as in examples (34) and (35), to express their certainty that the investigation and Janeva are not to be believed, aiming to create a negative frame of the work of the SPP. For instance, in (34) by using the verb "show" which is defined in Merriam-Webster dictionary as "to demonstrate or establish by argument or reasoning", the author clearly wants to discredit the rationale for any kind of investigation.

\footnotetext{
${ }^{10}$ Hyland's $(1998,2005)$ division of metadiscourse markers into textual and interpersonal was adopted for the purposes of this analysis.
} 
(34) This is what the ridiculousness and the absurd in the rationale for investigation show ... (the Republika)

\section{Janeva bombarded with criticism... (the Večer )}

- adjectives such as obvious, as in (36), again to persuade readers that the investigation is a scam. "Obvious" refers to "easily discovered, seen or understood" and the writer uses it to accuse the SPP for working with a previously prepared plan or agenda against the Government.

(36) It is obvious that the SPP prepared this plan for months. (the Večer)

- nouns, such as the fact, as in (37), to discredit the work of the prosecution:

(37) this leads us to the fact that the job done by the SPP is set to support a specific party (the Republika)

- repetitions of specific phrases, to influence the readers' opinion of the SPP's work. Examples (38)-(40) represent the most frequently repeated phrases:

$$
\text { ... this is just a request for investigation and not bill of indictment... }
$$

... this is just a call for investigation ...

Furthermore, the journalists who wrote for these two newspapers also used numerous attitude markers (adjectives or adverbs) to express their rather negative stance towards the presented propositional content. The examples (41)-(45) show that the journalists from both newspapers are critical of the work of the SPP, accusing it for working in favour of the opposition party's interests: the SPP has absurd, unfounded, scant and unsubstantiated doubts that the Government committed some kind of crime. These unfounded claims lead to conclusion that their sole purpose was to cause political harm.

(43) The accusation act of Janeva is based on allegedly 35 thousand IDs found. (the Večer)

(44) It is important to discover how these fake IDs came in SPP 's possession... (the Večer) 
... the overall and inevitable conclusion is that the SPP of Katica Janeva aims to ensure detention without any arguments but it solely aims to cause political harm. (the Republika)

The American journalists, on the other hand, avoided using intensifiers, but used hedges and attitude markers instead. For instance, the hedges employed in the USA Today's article help the writer mitigate their statements when trying to create a positive image of Trump and his nomination:

(46) Trump has been an outspoken critic of President Obama and was perhaps the most prominent voice of the "birther" movement. (the USA Today)

(47) Now that he's in, it's safe to predict he won't be pulling many punches with his rivals. (the USA Today)

The journalists writing for the USA Today and the New York Post also used attitude markers (mostly adverbs and adjectives) to frame Trump, his speech and nomination positively. He was described as a tough negotiator (the USA Today), while his speech as red-meat (the New York Post), and rambling (the USA Today), and his oratory style as: moxie and pugnacious (the New York Post).

In contrast, the journalists in The New York Times and the New York Daily News used hedges (such as seem, appear, may, might) to decrease the effect of their harsh comments against Trump (48) or his candidacy (49) and (50).

(48) Until now, Mr. Trump may be best known politically for his outspoken skepticism... (The New York Times)

(49) It seems a remote prospect that Republicans, (...) would rebound by nominating a real estate magnate... (The New York Times)

(50) A crowd that appeared to number in the hundreds - though Trump described it as "thousands". (the New York Daily News)

In addition, these journalists employed attitude markers to express their subjective, negative attitude towards Trump and his nomination. Their aim was obviously to discredit his reputation and influence the readers' opinion of him. For instance, they used the following modifiers (adjectives and adverbs mostly) that function as attitude markers to describe:

- him (Trump): garrulous real estate developer, formidable man of affairs, widely disliked, unfavorable view of him (The New York Times), made a less-than-imperial entrance, blunt-spoken billionaire (The New York Daily News); and also some verbs like: bragged, slammed, ridiculed, he insulted 
Mexican immigrants, derided foreign countries and lambasted President Obama (the New York Daily News);

- his speech: bragged extensively, has spoken contemptuously (The New York Times), jaw-dropping ad-libbed speech, disparaging comments, sedate, prepared remarks, eyebrow-raising statements, unconventional announcement (the New York Daily News);

- his nomination: improbable quest for the Republican nomination (the New York Times)

The analysis of both Macedonian and American texts revealed some cultural and stylistic differences between journalists from the two countries. Macedonian journalists who worked for newspapers supportive of the Government and against the SPP tended to use more intensifiers to express their negative attitude towards the activities of the SPP, while American journalists in general avoided using intensifiers but resorted to a larger number of hedges. Those in support of Trump tended to hedge their positive statements of him, while those who wrote against his nomination, used hedges to lower the effect of their harsh criticism. Attitude markers, on the other hand, were used by writers in both samples of texts to convey either their positive or negative attitude towards the person or event presented. The use of interpersonal markers shows that journalists are inclined to modify their statements to frame the news either negatively or positively and thus influence the readers' opinion.

\subsubsection{Evidentiality}

Since its first mention by Boas (1938), evidentiality has been studied from different perspectives. Studies have shown that evidentiality can be coded by grammar and/or lexis, depending on the language. In the Macedonian language, according to Tofoska (Тофоска 2011: 41), evidentiality can be expressed through lexical and grammatical language devices and can be both direct (when the utterance shows that the source of knowledge is the personal, direct perception of the situation by the writer) and indirect (when the utterance indicates that the writer did not witness the situation directly but retells it indirectly).

This paper takes a metadiscourse perspective on evidentiality. Evidentials are defined as textual metadiscourse markers, which are used by writers to organise the text and give directions to readers as to how they should read and interpret the text (Hyland 2005). Evidentials help the writer to base a certain standpoint on information from another source (Hyland 1998, 2005). With their help, writers integrate their statements into the already existing knowledge or stated facts and thus, they gain greater credibility and become more persuasive for the readership. According to Leech (1983), internal intertextuality, or the relation of the text to other texts, is typical for news reporting which is supposed to reproduce the actions and opinions of others (quotation and reported speech). 


\subsubsection{Macedonian data}

The analysis of the Macedonian texts showed that they were all marked for evidentiality, which was almost always indirect (citing and retelling). However, what raises serious doubts, especially in the texts published in the Republika and the Večer is the vagueness in citation the source of information.

In the Republika the sources were vague and unconfirmed: for instance, in (51) the writer refers to some, unknown experts and in (52) to certain, but unspecified sources.

(51) The pumping of the atmosphere by the opposition and the prosecutors is done for marketing purposes, say the experts.

(52) According to certain sources, the SPP has gone that far to request detention for people with no material evidence.

However, the words experts and certain sources are misleading because they might falsely lead the reader to infer that the arguments should be trusted because they come from reliable sources.

In the Večer, the journalist used direct quotations, but they also, for the most part, expressed their own, rather subjective opinion. In the Utrinski Vesnik and the Deutsche Welle, on the other hand, direct citations prevailed or the exact sources were stated (SPP, prosecutors or experts involved):

$$
\text { Fetai stated that "in } 2012 \text { the suspects [...]" (the Utrinski Vesnik) }
$$

\subsubsection{American data}

The analysis of the American texts showed that all 4 articles were marked for evidentiality, which was mostly indirect (they were either citing others or retelling). For instance, in the USA Today the journalist used both direct (journalist's personal perception) combined with indirect evidentiality (Trump, as well as other sources):

(54) Trump made the announcement at Trump Tower in New York, descending on an escalator...

(55) Nathan Gonzales, editor of nonpartisan Rothenberg and Gonzales Political Report, called him an unwelcome distraction for the GOP. "It's a big headache for the Republican Party," he said.

The journalist in the New York Post used direct evidential strategy, but also cited or retold Trump's words. In The New York Times, they expressed their subjective 
opinion for the most part, but also employed evidentials by retelling the event or citing Trump's or experts' words (see examples below).

$$
\begin{aligned}
& \text { "He's got that celebrity status," Mr. Ruddy said. "Republicans sort of } \\
& \text { crave that, because we don't have it, generally." }
\end{aligned}
$$

A recent Quinnipiac University poll found that about seven in 10 voters nationally hold an unfavorable view of him, including 52 percent of Republicans.

In The New York Daily News journalist mostly expressed their subjective opinion by commenting on Trump's speech, but also used evidentials to report comments made by some unknown attendants.

$$
\begin{aligned}
& \text { Eli Profeto, 19, said he attended out of curiosity. "I'm from Indiana and } \\
& \text { we don't have things like this every day," he said. "It was definitely } \\
& \text { different." }
\end{aligned}
$$

The data show that the journalists writing for The New York Times and the New York Daily News were rather subjective and biased when reporting on the event, and they rarely relied on other sources to support their arguments.

The analysis of both Macedonian and American articles showed that all the texts were marked for evidentiality, which was almost always indirect (citing and retelling). However, the newspapers which are known to be critical of a person or event (against the work of SPP in Macedonia and against Trump in the USA) used rather vague and unconfirmed sources. They wrote subjective, negative opinions, in comparison to the more neutral newspapers which mostly relied on direct citations stating the exact sources or retelling speakers' words.

\subsection{Rhetorical tropes}

The last aspect of the analysis deals with the usage of rhetorical tropes in the articles. Corbett (1990: 426) defines a trope as 'a deviation from the ordinary and principal signification of a word'. Writers use words to denote or connote something apart from their ordinary meaning and in this way they try to modify their statements and present their personal opinion with the aim to shape readers' opinions about the topic at stake. The usage of three figures of speech or tropes was investigated in two samples of newspaper articles:

a) metaphor: most basically described as "a type of figurative language in which one thing is described in terms of some other thing" (Song 2011: 68). The analysis is focused on the most prominent metaphors employed by journalists to describe the political figure or entity presented in their texts. 
b) metonymy: defined as "a type of figurative language in which the name of one thing is replaced with another commonly associated with it" (Song 2011: 69). The analysis identifies the metonymy used by journalists to substitute for the political figures or entities they write about.

c) irony: two types were considered: (a) counterfactual irony when the author states one thing and intends to convey something and (b) truth-telling irony - when he/she states exactly what he/she means but their intention is to criticize or express their disapproval with somebody (Martin 1992; Gibbs 2000; Neškovska 2014).

Grice, in his essay from 1975, "Logic and Conversation", grouped together metaphor and irony (with sarcasm implicitly subsumed in the latter) implicatures generated in acts of flouting the maxim of quality or truthfulness (Musolff 2017). They are often used in political discourse to add to the persuasive effect. Journalists writing in favour or against certain politicians employ these figures of speech to manipulate the readers' opinion and frame politicians or political events positively or negatively.

The analysis of the Macedonian texts showed that it was mostly in the Republika and the Večer that the writers used rhetorical tropes. For instance, examples (59) and (60) feature the use of metaphors in the Republika with a negative connotation. In (59) the journalist presents SPP as a cook, but a bad cook who mixes the pots and produces chaos. In (60) the author uses metaphor and compares the work of the SPP to folklore, which is politically inspired.

\section{The SPP mixed the pots. (the Republika)}

(60) One cannot ignore or put away this whole politically inspired folklore when assessing the work of the SPP. (the Republika)

Examples (61)-(63) feature the use of irony, seasoned with metaphor and metonymy. Example (61) is a well-defined case of a truth-telling irony because the writer openly criticises the work of the SPP. The journalist in (62) uses metonymy to make an association of the investigation with the intentional pursuit the opposition party's agenda, as well as irony to criticise the work of SPP. In (63), the journalist uses metaphor (Katica Janeva's "job" is compared to a rescue mission to save Zaev) and truth-telling irony to express open criticism.

(61) The legal amateurism and improvisation while compiling the cases is a serious problem which made SPP notoriously famous. (the Republika)

(62) Janeva's accusations and the "thorough investigation" are nothing more than simply pursuing the agenda in favour of the SDSM leader, Zoran Zaev. (the Večer) 
(63) She believes that the obstructions against her and the SPP will continue, but that they won't stop her in her "job", i.e. her mission to "come to Zaev's rescue". (the Večer)

Rhetorical tropes were found in the American corpus as well. For instance, the journalist in the New York Daily News used a rather insulting metaphor to describe and thus negatively frame Trump as inadequate and someone who just entertains the audience, comparing him to:

(64) a clown, with red rubber nose which he threw into the ring

Authors also used metonymy to describe Trump as:

$$
\text { the mogul, the real-estate developer (the New York Post) }
$$
the garrulous real estate developer (The New York Times)

the real estate magnate, the blunt-spoken billionaire (the New York Daily News)

Journalists also mocked Trump and his nomination by using irony as in examples (68)-(71) below. For instance, (68) is a subtle example of a truth-telling irony: the journalist mentions the books Trump has published aiming to make fun of him and present him as inadequate presidential candidate with no political background and experience. Similarly, in (69) the New York Daily News journalist uses irony to make fun of Trump's abilities to run the country. Being wealthy does not imply being politically successful. Furthermore, in (70), the journalist of the New York Daily News is being ironic by using the clown metaphor - Trump is compared to a clown, which presents him as completely inappropriate and incapable for doing serious work like leading a whole nation and country. In (71) the author is alluding directly to Mr. Trump's statement (that thousands of people came to support him), showing disagreement and contempt. The journalist openly downplays and mocks the whole event.

(68) It seems a remote prospect that Republicans, (...), would rebound by nominating a real estate magnate who has published books with titles such as, "Think Like a Billionaire" and "Midas Touch: Why Some Entrepreneurs Get Rich - And Why Most Don't." (The New York Times)

(69) He went on to tout his wealth as proof he could run the country. (the New York Daily News) 
(70) The carload of Republicans running for president now has a clown. Billionaire Donald Trump threw his red-rubber nose into the ring Tuesday with a jaw-dropping ad-libbed speech... (the New York Daily News)

(71) A crowd that appeared to number in the hundreds - though Trump described it as "thousands" - gathered wearing "TRUMP: Make America Great Again!" shirts to hear the blunt-spoken billionaire. (the New York Daily News)

The analysis of the rhetorical tropes used in both Macedonian and American articles showed that journalists writing critically of the reported entity or person (SPP in Macedonia and Trump in the USA) tended to use metaphor and irony (truth-telling) as rhetorical tropes to mock, ridicule or simply criticise politicians or political institutions.

\section{Conclusion}

This paper presented the results of the critical discourse analysis of journalistic texts from different American and Macedonian newspapers. The main goal was to determine the specific language tools (lexical-semantic, pragmatic and stylistic) journalists use to twist the truth or present it from a specific angle. The contrastive analysis of journalistic texts with different political affiliation enabled to filter out some cultural and stylistic differences between the articles from the two, culturally different, societies (Macedonian and American).

The analysis resulted in positive answers to the two research questions and confirmed all the three hypotheses. Firstly, it revealed the interrelatedness between textual form and content: the same news story laid out in different ways has different meanings. Journalists made cautious language choices to provoke a specific readership reaction and build their opinion about issues of political and social importance. The lexis was carefully selected to frame the work of the SPP (in the Macedonian texts), and Trump (in the American texts) either negatively or positively, depending on the political orientation of the newspaper. The pragmatic analysis further showed that Macedonian authors used intensifiers to increase the negative attitude towards the work of the SPP or the positive towards the opposition, while American authors tended to use hedges to mitigate the harshness of their criticism towards Trump. This might be an indication of a cultural or a stylistic difference of the journalists' perception of the persuasive effect of these markers in the two societies or simply difference in the manner journalists from the two societies write about political issues. However, in order to confirm this assumption, a more detailed analysis is needed.

Furthermore, the analysis showed that both samples of texts were marked for evidentiality, but the texts of the more politically-oriented newspapers were written 
more subjectively. The authors relied on undocumented or vague sources to support their subjective opinions. Finally, the analysis of the rhetorical tropes showed that writers used mostly metaphors and irony to negatively frame the SPP (in the Macedonian texts) and Trump (in the American texts). Overall, it was confirmed that journalists from both countries take sides, which is reflected in the choice of manipulative language strategies. The analysis revealed that journalists from both countries make a careful selection of strategies to present certain news from a specific angle. Generally, those oriented towards some political option attempted to support it and present it positively. Consequently, they attacked the other by presenting the negative aspects. Finally, the analysis uncovered the both countries' written media's hidden values and ideologies, which propagate injustice through abusing their power to inform the readers objectively of the political situation.

\section{References}

Bednarek, M. (2006). Evaluation in media discourse: Analysis of a newspaper corpus. London: Continuum.

Boas, F. (1938). Language. In F. Boas (ed.). General anthropology, 124-145. Boston, New York: D.C. Heath.

Corbett, P. J. E. (1990). Classical rhetoric for the modern student ( $3^{\text {rd }}$ edn.). New York: Oxford University Press.

Entman, M. R. (2007). Framing bias: Media in the distribution of power. Journal of Communication, 57 (1): 163-173. [Online] Available from: https://doi.org/10.1111/j.1460-2466.2006.00336.x

Fairclough, N. (1995). Media discourse. London: Bloomsbury Academic.

Fowler, R. (1991). Language in the news: Discourse and ideology in the press. London: Routledge.

Gibbs, W. R. Jr. (2000). Irony in talk among friends. Metaphor and Symbol, 15 (1/2): 5-27. [Online] Available from: https://doi.org/10.1080/10926488.2000.9678862

Goffman, E. (1974/1986). Frame analysis: An essay on the organization of experience. New York: Harper and Row.

Hyland, K. (1998). Persuasion and context: The pragmatics of academic metadiscourse. Journal of Pragmatics, 30 (4): 437-455. [Online] Available from: https://doi.org/10.1016/S0378-2166(98)00009-5

Hyland, K. (2005). Metadiscourse:Exploring interaction in writing. Bodmin, Cornwall: MPG Books.

Lakoff, G. (2004). Don't think of an elephant! Know your values and frame the debate. White River Junction, Vt.: Chelsea Green.

Leech, G. (1983). The principles of pragmatics. London: Longman.

Martin, R. (1992). Irony and universe of belief. Lingua, 87: 77-90. [Online] Available from: https://doi.org/10.1016/0024-3841(92)90026-F

Musolff, A. (2017). Metaphor, irony and sarcasm in public discourse. Journal of Pragmatics, 109: 95-104. [Online] Available from: http://dx.doi.org/10.1016/j.pragma.2016.12.010 
Neškovska, S. (2014). Types of verbal irony. Journal of Process Management - New Technologies International, special edition: 658-662. [Online] Available from: http://www.japmnt.com/images/SpecialEdition2014/121.\%20TYPES\%20OF\%20VER BAL\%20IRONY.pdf

O'Keeffe, A. (2011). Media and discourse analysis. In J. Gee and M. Handford (eds.). The Routledge handbook of discourse analysis, 441-454. London: Routledge. Available from: https://dspace.mic.ul.ie/bitstream/handle/10395/1681/O\%20?sequence=2

Richardson, J. (2007). Analysing newspapers: An approach from Critical Discourse Analysis. London: Palgrave Macmillan.

Reah, D. (2002). The language of newspapers. London: Routledge.

Reisigl, M. and Wodak, R. (2001). Discourse and discrimination: Rhetorics of racism and antisemitism. London: Routlege.

Shenli, S. (2011). Metaphor and metonymy - A tentative research into modern Cognitive Linguistics. Theory and Practice in Language Studies, 1(1): 68-73.

DOI: $10.4304 /$ tpls.1.1.68-73

Simpson, P. (1993). Language, ideology and point of view. London: Routledge.

Talbot, M. (2007). Media discourse: Representation and interaction. Edinburgh: Edinburgh University Press.

Van Dijk, A. T. (1991). Racism and the press. London: Routledge.

Van Dijk, A. T. (2006). Discourse and manipulation. Discourse and Society, 17(2): 359383. [Online] Available from: https://doi.org/10.1177/0957926506060250

Van Dijk, T. A. (2009). Critical discourse studies: A sociocognitive approach. In R. Wodak and M. Meyer (eds.). Methods of critical discourse analysis, 62-86. London: Sage. Available from: http://www.discourses.org/OldArticles/Critical\%20discourse\%20studies.pdf.

Wadi, S. I and Ahmed, A.A. (2015). Language manipulation in media. International Journal on Studies in English Language and Literature (IJSELL), 3 (7): 16-26. [Online] Available from: https://www.arcjournals.org/pdfs/ijsell/v3-i7/3.pdf

Wheeldon, J. and Faubert, J. (2009). Framing experience: Concept maps, mind maps and data collection in qualitative research. International Journal of Qualitative Methods, 8 (3): 68-83. [Online] Available from: https://doi.org/10.1177/160940690900800307

Tофоска, С. (2011). Verba dicendi како лесички показатели на евиденцијалноста и нивниот сооднос со граматичките показатели за евиденцијалност во македонскиот јазик. Перифрастични конструкции со ESSE и HABERE во словенските и балканските јазищи, 41-53. Скопје : МАНУ. 